\title{
Volumetric Variation and Rheology of Cement Based Mineral Additions (Blast Furnace Slag and Silica Fume)
}

\author{
Meriem Laakri, Mohamed Nadjib Oudjit and Kamel Abdelli \\ Civil Engineering Department, University of Science and Technology Houari Boumediene (USTHB), Algiers 16111, Algeria
}

\begin{abstract}
The partial substitution of clinker by mineral additions offers very significant, both economical and environmental benefits. This adds value to industrial waste, and contributes also in the preservation of natural resources, like clay and limestone, as well as the reduction of greenhouse gas emissions $\left(\mathrm{CO}_{2}\right)$. This study is interested in the simultaneous effect of BFS (blast furnace slag) and SF (silica fume) on setting time and water requirement of cement paste. The volumetric variations are tested in mortars, prepared in the same mixture of pastes, and the tests indicate that the addition of slag increase the fluidity, reduce the water demand, shrinkage and expansion, compared to the mortar, containing ten percent (10\%) of Silica Fume only. The images of pastes obtained by SEM (scanning electron microscopy), are indicated an improvement of the microstructure of the paste with a large amount of slag, which leads to improve durability.
\end{abstract}

Key words: Cement rheology, blast furnace slag, silica fume, shrinkage, expansion, microstructure.

\section{Introduction}

Significant development facing the construction sector in Algeria needs to request new concrete technology, and use of economic, efficient and easily available materials.

The cement producers in Algeria use more and more cement additives in cement manufacturing, such as fine limestone, natural pozzolans and blast furnaces slag in order to satisfy the increasing demand for this material.

The use of mineral additives, allows to obtain different types of cement, with physical and mechanical properties adapted to needs [1]. The used cement should be stable, because the risk of expansion over time can cause significant disorders [2]. Portlandite $\left(\mathrm{Ca}(\mathrm{OH})_{2}\right)$, generated during the hydration of cement, causes an increase in volume, the fixing thereof by pozzolanic additions like blast furnace slag and silica fume, leads to a reduced expansion [3].

The blast furnace slag improves most properties of the fresh and hardened concrete, especially in the

Corresponding author: Meriem Laakri, Ph.D. student, research fields: building materials and sustainable development. E-mail: lakrimeriem@yahoo.fr. presence of superplasticizer and silica fume. Other aspects, such as shrinkage still subject to debates [4]. Lura [5] found out that concrete slag-based cement leads to a higher autogenous deformation than portland cement concrete. On the other hand, Regourd [6] for her part, noted that the shrinkage in slag cement is lower than that of OPC (ordinary portland cement), to a much higher fineness. The effect related to the presence of fine grains would be, according to her, compensated by the crystallization of needles of Ettringite (Ett).

Our work is a contribution to the study of the influence of blast furnace slag and silica fume on the rheology and volumetric variation of cement. The Vicat apparatus is used to determine consistency, and informs us about the period during which the concrete can still be used. The scanning electron microscope shows the changes that occur in the microstructure in the different pastes.

\section{Laboratory Test}

\section{1 Characterisation of Material}

The materials used in this study are: 
- Portland cement CEM I 42.5;

- Blast furnace slag from the steel factory of "El Hadjar", Algeria;

- Silica fume;

- A kind of superplasticizer (polycarboxylate), highly water reducer. It comes in liquid form, dosed at $40 \%$ solid by mass of cement, density is 1.08 and $\mathrm{pH}$ 5.7 , which is used as an addition to make of the mortar only.

\subsubsection{Chemical Analyzes of Powders}

The cement and mineral admixture (BFS and SF) are used for all tests, both mortar and cement pastes. The results of chemical analysis of powders are given in Table 1.

\subsubsection{Evaluation of Slag Hydraulicity}

The chemical composition is a simple and decisive factor in defining slags hydraulicity. Therefore, modules and activity indices were established to assess the hydraulic slags. These indices define the basic or acidic nature of the slag, according to whether they are respectively, above or below unity.

The optimal index of hydraulicity, noted $I_{h}$, of blast furnace slag is defined as the ratio of the basic fraction over the acid fraction [2].

$$
I_{h}=\frac{\% \mathrm{CaO}}{\% \mathrm{SiO}_{2}}
$$

The indice of hydraulicity was calculated by using Eq. (1), $I_{h}=1.34>1$, and the blast furnace slag of El Hadjar (Algeria) is basic. Then it can be used in the cement industry.

\subsection{Setting and Consistence Tests}

Setting and consistence tests were performed according to standard (EN 196-3).

The control P0 and the different pastes P10, P20, P30 are prepared as shown in Table 2.

- $\mathrm{P} 0$ (OPC, 10\%FS, 0 BFS);

- P10 (OPC, 10\%FS, $10 \mathrm{BFS}$ );

- P20 (OPC, 10\%FS, 20 BFS);

- $\mathrm{P} 30$ (OPC, 10\%FS, $30 \mathrm{BFS}$ ).

Normal consistency of cement pastes, according to standard, is obtained when the plunger penetrates up to a distance of $6 \pm 1 \mathrm{~mm}$ from the bottom of the mould.

Setting tests taken on different mixtures were prepared with a constant $(\mathrm{W} / \mathrm{S})$ ratio, equal to 0.285 , corresponding to the normal consistency of the control paste.

The Vicat test consists in monitoring the state transformation of viscous material, easy to work in the form of a cured material, by applying the following formula:

$$
\tau=\frac{P}{S_{l}-10 S_{p}}
$$

where,

$P$ : the applied load $(P=300 \mathrm{~g})$;

$S_{l}$ : the tip of the lateral surface of needle diameter $\varnothing$ : $\mathrm{Sl}=(40-\mathrm{d}) \pi \varnothing ;$

$S_{p}$ : the cross section of the needle: $S_{p}=\left(\pi \varnothing^{2}\right) / 4$;

$\tau_{0}$ : shear corresponding to the time of initial setting.

The start setting time is determined when the Vicat needle (diameter $=1.13 \mathrm{~mm}$ ), penetrates up to a distance $(d=4 \mathrm{~mm})$.

Table 1 Chemical composition of OPC and mineral additives.

\begin{tabular}{llll}
\hline Chemical composition (\%) & OPC & SF & BFS \\
\hline $\mathrm{SiO}_{2}$ & 21.86 & 96.00 & 33.26 \\
$\mathrm{Al}_{2} \mathrm{O}_{3}$ & 3.8 & 0.90 & 10.00 \\
$\mathrm{Fe}_{2} \mathrm{O}_{3}$ & 4.83 & 0.60 & 1.06 \\
$\mathrm{CaO}$ & 60.48 & 1.53 & 44.57 \\
$\mathrm{MgO}$ & 2.20 & 0.20 & 4.66 \\
$\mathrm{SO}_{3}$ & 1.89 & 0.45 & 0.20 \\
$\mathrm{Na}_{2} \mathrm{O}$ & 0.17 & 0.17 & $/$ \\
$\mathrm{CaO}($ libre $)$ & 0.74 & $/$ & $/$ \\
$\mathrm{K}_{2} \mathrm{O}$ & 0.47 & 0.90 & $/$ \\
$\mathrm{Cl}-$ & 0.04 & $/$ & $/$ \\
$\mathrm{Ins}$ & 0.60 & $/$ & $/$ \\
$\mathrm{PF}$ & 1.71 & $/$ & 0.44 \\
Specific gravity $\left(\mathrm{g} / \mathrm{cm}^{3}\right)$ & 1.12 & 0.5 & 1.2 \\
Specific gravity $\left(\mathrm{g} / \mathrm{cm}^{3}\right)$ & 3.18 & 2.2 & 2.88 \\
$\mathrm{Blaine}$ surface area $\left(\mathrm{cm}^{2} / \mathrm{g}\right)$ & 3,250 & $/$ & 5,300 \\
$\mathrm{BET}$ surface area $\left(\mathrm{cm}^{2} / \mathrm{g}\right)$ & $/$ & 200,000 & $/$ \\
\hline
\end{tabular}

Table 2 Composition of the pastes with cement and additions.

\begin{tabular}{lllcl}
\hline Samples & OPC $(\mathrm{g})$ & SF $(\mathrm{g})$ & $\mathrm{BFS}(\mathrm{g})$ & $\mathrm{W} / \mathrm{S}$ \\
\hline P0 & 450 & 50 & 0 & 0.285 \\
P10 & 405 & 50 & 45 & 0.285 \\
P20 & 360 & 50 & 90 & 0.285 \\
P30 & 315 & 50 & 135 & 0.285 \\
\hline
\end{tabular}




\subsection{Shrinkage and Expansion Tests}

Tests of shrinkage and expansion are carried out on samples $\left(4 \times 4 \times 16 \mathrm{~cm}^{3}\right)$ in mortars, according to standard (NF P15-433). They are prepared with a constant $\mathrm{W} / \mathrm{S}$ ratio, equal to 0.45 .

About Conservation of Samples, the specimens tested are preserved at a temperature of $20 \pm 2{ }^{\circ} \mathrm{C}$ :

- in fresh water $(100 \% \mathrm{RH})$ for expansion testing;

- in the open air $(65 \% \mathrm{RH})$ for shrinkage testing.

\subsection{Microstructure Test}

The SEM (scanning electron microscopy) allows to identify the nature and morphology of the hydrates formed. The materials used are non-conductive, and the paste samples were previously metalized to make them conductive.

\section{Results}

\subsection{Effect of Additions in Consistence of Pastes}

Consistency tests were carried out on mixtures of pasta, and this test shows the influence of the percentage of slag in the normal consistency of paste.

Fig. 1 shows that the addition of slag tends to reduce water demand. The $\mathrm{W} / \mathrm{S}$ corresponding to a normal consistency in the slag pastes is lower than the control (P0), thus implying a better flow of the paste due to the lubricating effect of the addition which has a higher fineness to the cement [7]. According to Benghazi [8], this is mainly due to the ratio $(\mathrm{Ca} / \mathrm{Si})$, which decreases with the increasing percentage of slag (rich in silica), which is more important than in Portland cements.

\subsection{Effect of Additions in Pastes Setting}

The curves shown in (Fig. 2) indicate that the shear in paste $\mathrm{P} 0$ remains low and fairly constant for nearly two hours $(2 \mathrm{~h})$, beyond this period, the shear increases sharply to a maximum value after $4 \mathrm{~h}$ and $52 \mathrm{~min}$, corresponding to the final setting time of the control paste. The evolution of the shear rate decreases in pastes containing slag, compared to the control.

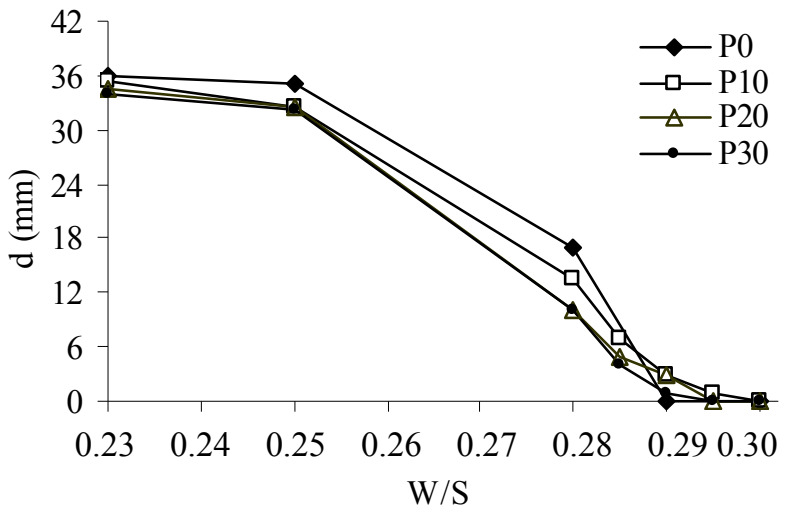

Fig. 1 Normal consistency of pastes P0, P10, P20, P30.

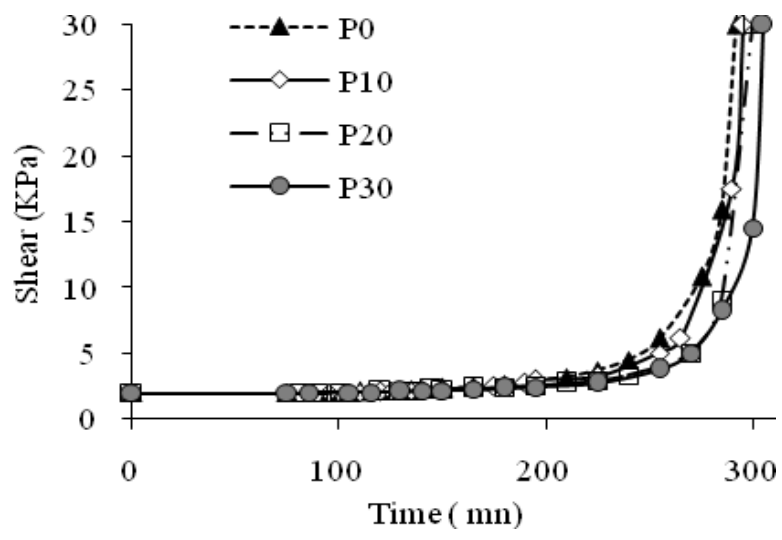

Fig. 2 Evolution of shear in the pastes.

This can be assigned to the extension of dormant period relatively to that of the control paste. This increase is also depending on the amount of slag contained in pastes. This is explained by the fact that the chemical reaction is delayed at the short range. The hydration of tricalcium silicate $\left(\mathrm{C}_{3} \mathrm{~S}\right)$ and tricalcium aluminate $\left(\mathrm{C}_{3} \mathrm{~A}\right)$ that compose the cement causes a thermal effect from the earliest times, and this accelerates the kinetics of hydration. When the amount of $\mathrm{C}_{3} \mathrm{~S}$ and $\mathrm{C}_{3} \mathrm{~A}$ is reduced during the substitution of cement by slag, the temperature decreases, and this decreases the rate of cement hydration by extending the dormant period [9].

The effect of the addition of blast furnace slag on the setting is small for low replacement rate. The effect of adding slag results in a proportional increase in time to initial and final setting. For P30, the initial setting time increased by $14 \mathrm{mn}$ and the final time increased by $13 \mathrm{mn}$.

The kinetic of hydration of the binder becomes 
more and more slowly, depending on the increase in the amount of the slag [10], and the crystals of calcium silicate hydrates (C-S-H), responsible for the phenomenon of hardening, are in small quantities to very young ages $[10,11]$.

\subsection{Volumetric Variations}

\subsubsection{Shrinkage}

The evolution of shrinkage of different mortars (Fig. 3) is fast at short range and tends to stabilize after 28 days. The progressive addition of slag induced a significant decrease of shrinkage in mortars. There is a shrinkage reduction of around $50 \%$ in mortar M30 compared to the control.

C-S-H gel formation in larger quantities due to the pozzolanic reaction slag creates a larger volume of micropores, and thus reduces shrinkage [12]. The presence of expansive phases such as Ettringite (Confirmed by SEM) also contributes to the reduction of shrinkage [6, 12].

\subsubsection{Expansion}

The curves in Fig. 4, show that the expansion increases rapidly at early age (before 3 days). Between 3 and 7 days the expansion progresses slowly, and tends to stabilize after 20 days, for all mixtures. The specimens containing $20 \%$ and $30 \%$ slag present much lower expansion than the control and the observed reductions are around $48 \%$ for M20 and $52 \%$ for M30.

The expansion observed after the setting is due to the formation of massive hydrate as Portlandite, $\mathrm{Ca}(\mathrm{OH})_{2}$, whose growth is putting pressure on the inner structure, and causes dilation (expansion of lime). This expansion is opposed in part to the shrinkage, and is related to the amount of free lime remaining unhydrated after starting the setting.

If the amount of Portlandite is reduced, the expansion is also reduced [13, 14]. The combined effect of the pozzolanic reaction of silica fume and blast furnace slag has reduced the expansion at short range and tends to stabilize it at long range. Moreover,

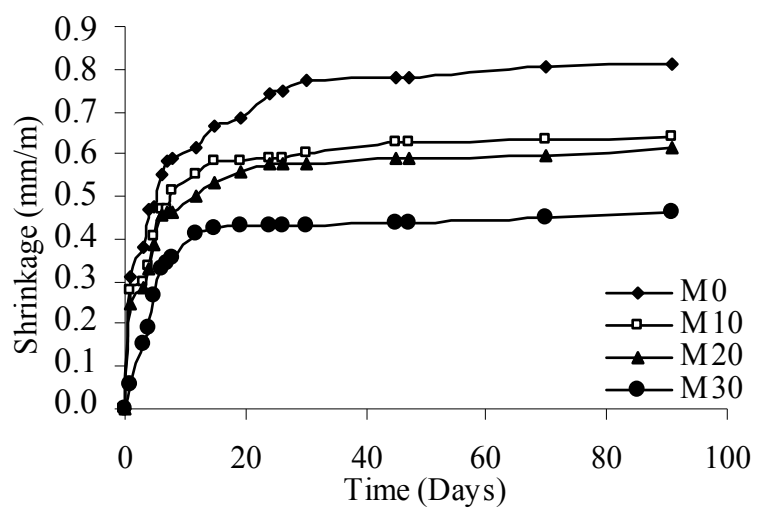

Fig. 3 Shrinkage in mortars.

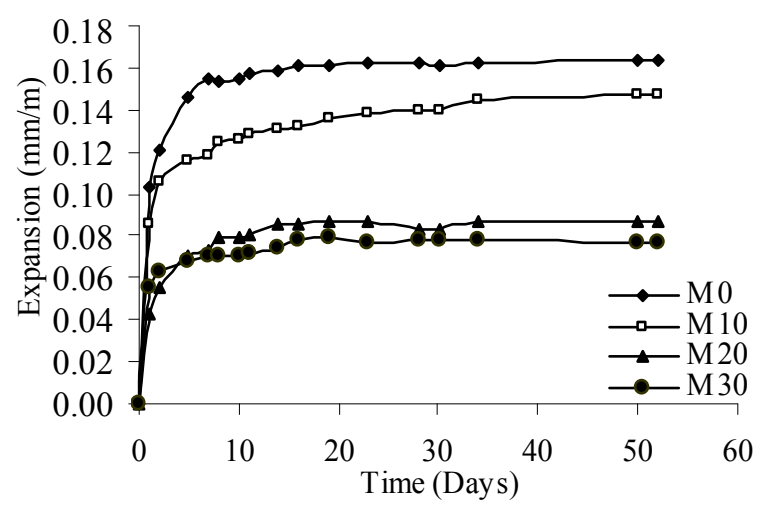

Fig. 4 Expansion of mortars.

the hardening dough becomes more dense and Impervious and the porosity of the slag cement paste decreases along time $[15,16]$. Ramlochana [17] found that in the case of a replacement close to $(8 \%)$ of silica fume into the concrete, expansion may only be delayed due to the low permeability of the mortar; on the other hand, the use of blast furnace slag in sufficient quantity may control the expansion.

\section{Microstructure of Pastes}

The images of pastes P0, P20, P30, obtained by SEM, after six months of hydration, reveal the nature and morphology of the hydrates formed.

The micrographs (Figs. 5-7) indicate the formation of calcium silicate hydrate (C-S-H), needles of Ettringite (Ett), and the monosulfoaluminate (MSA), caused by the transformation of Ettringite after exhaustion of gypsum resulting from the pozzolanic reaction. 


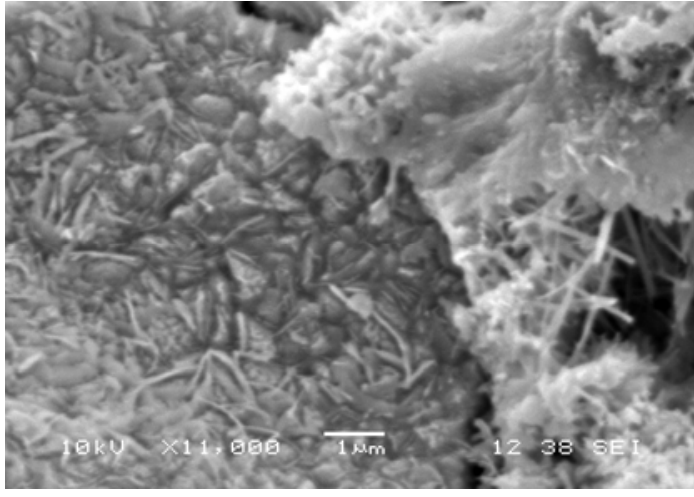

Fig. 5 Presence of Ettringite in P30 sample paste.

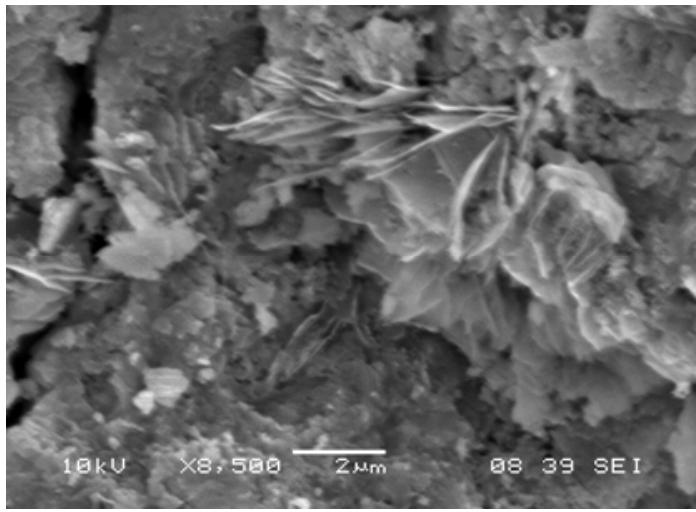

Fig. 6 Formation of MSA in P0.

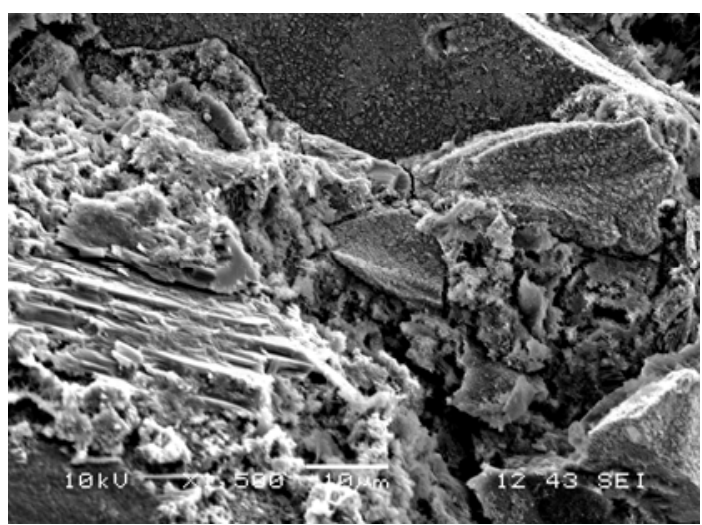

Fig. 7 Sample past P30, with $\mathbf{3 0 \%}$ of slag.

Fig. 7 illustrates fine dense C-S-H in pastes with $30 \%$ of slag, following the formation of additional hydro-calcium silicates (C-S-H). The presence of MSA (Fig. 6) is less important in the paste with slag compared to the control that reflects improvement in durability $[16,18]$.

\section{Conclusions}

The addition of slag tends to reduce the water demand and so increases the fluidity of pastes for the same water to solid ratio. The effect of slag in setting is minimal for rates replacement up to $30 \%$, and it can be greater for more important values.

The gradual replacement of cement by slag induced a significant decrease in the shrinkage, in the ternary mixtures. There was a reduction of around $69 \%$ for the total shrinkage in the M30 mortar at 28 days.

The combined effect of pozzolanic reaction of blast furnace slag and silica fume formed a supplementary calcium silicate hydrate [19], that results in a dense matrix (confirmed by SEM), which leads in enhances of durability in concretes.

\section{References}

[1] J. Alexender, J.L. Sebileau, Le Laitier de Haut Fourneau, Elaboration, Traitement, Propriétés, Emplois, Edition CTPL (Centre Technique et de Promotion des Laitier), Paris, 1988, p. 340.

[2] M. Venuat, La pratique des ciments et du béton, Edition le Moniteur, 1976.

[3] K. Salhi, B. Mezghiche, Etude de durabilité de mortier et béton contenant de ciment avec ajout de laitier et sable de Dune, in: 1st International Conference on Sustainable Built Environment Infrastructures in Developing Countries ENSET Oran, Algeria, Oct. 12-14, 2009.

[4] M. Lanez, Contribution à l'étude de béton de poudre réactives, Magister Thesis, University of Science and Technology Houari Boumediene, 2005.

[5] P. Lura, K. van Breugel, I. Maruyama, Effect of curing temperature and type of cement on early-age shrinkage of high-performance concrete, Cement and Concrete Research 31 (2001) 1867-1872.

[6] M. Regourd, Structure et Comportement des Hydrates des Ciments au Laitier, in: 7th International Congress, Paris, France, 1980.

[7] F. de Larrard, Durabilité des bétons à haute performance: réaction alcalis granulats et carbonatation, Edition ENPC (Ecole Nationale des Ponts et Chaussées), 1992, pp. 255-269.

[8] Z. Benghazi, L. Zeguichi, A. Hamdane, Study of alkali-activated pozzolana/slag cement, based on local materials which has a higher $(\mathrm{Ca} / \mathrm{Si})$ ratio, in: 1st International Conference on Sustainable Built Environment Infrastructures in Developing Countries ENSET Oran, Algeria, Oct. 12-14, 2009.

[9] V. Baroghel-Bounty, Caractérisation des pâtes de ciment et des bétons, Edition LCPC (Laboratoire Central des 
Ponts et Chaussées), 1994.

[10] M. Heikal, I. Aiad, I.M. Helmy, Portland cement, clinker, granulated slag and by-pass cement dust composites, Cement and Concrete Research 32 (2002) 1805-1812.

[11] A. Naceri, I. Messaoudene, Effet de l'activation mécanique du laitier de Haut Fourneau sur le comportement mécanique du mortier, Lebanese Science Journal 7 (2) (2006) 85-96.

[12] M. Michel, Accélération du ciment au laitier par du ciment sulfoalumineux, Ph.D. Thesis, National Institue of Applied Sciences Lyon, Jan 28, 2009.

[13] R. Dupain, R. Lanchon, J.C. Saint-Arroman, granulat sols, ciment et bétons, Edition Casteilla, 2004.

[14] K. Salhi, B, Mezguiche, Etude de durabilité de mortier et béton contenant de ciment avec ajout de laitier et sable de Dune, in: 1st International Conference on Sustainable Built Environment Infrastructures in Developing Countries ENSET Oran, Algeria, Oct. 12-14, 2009.

[15] L. Boubeker, Elaboration et étude d'un béton à hautes performances, Magister Thesis, ENP (Ecole Nationale Polytechnique), 1999.

[16] S.P. Pandey, R.L. Sharma, L'influence des additifs minéraux sur la force et la porosité du mortier d'OPC, Cement and Concrete Research 30 (2000) 19-23.

[17] T. Ramlochan, P. Zacarias, M.D.A. Thomas, R.D. Hootona, The effect of pouzzolans and slag on the expansion of mortars cured at elevated temperature, Part I: Expansive behaviour, Cement and Concrete Research 33 (2003) 807-814.

[18] S.C. Pala, A. Mukherjee, S.R. Pathak, Investigation of hydraulic activity of ground granulated blast furnace slag in concrete, Cement and Concrete Research 33 (2003) 1481-1486.

[19] M. Laakri, K. Abdelli, M.N. Oudjit, Hydratation de pâtes de ciment a base de laitier de haut fourneau et de fumée de silice, in: 2nd International Congress on Technology and Durability of Concrete, CITEDUB 2, Algeria, Nov. 2011. 